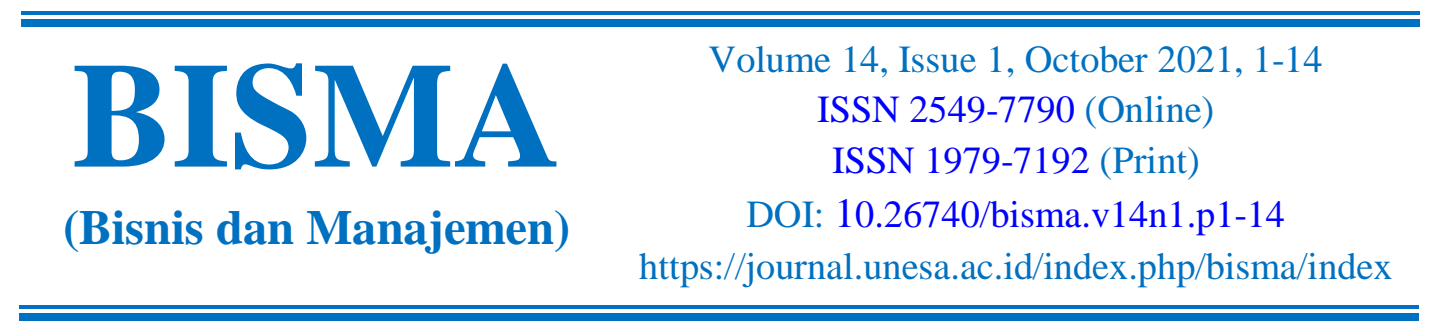

\title{
The effect of money attitude, subjective norm, perceived behavioural control, and perceived risk on millennial's saving intention
}

\author{
Nadia Asandimitra ${ }^{1 *}$, I Made Narsa ${ }^{2}$, Andry Irwanto ${ }^{3}$, Helmi Ishartanto ${ }^{4}$ \\ 1,2,3 Universitas Airlangga, Indonesia \\ ${ }^{1}$ Universitas Negeri Surabaya, Indonesia \\ ${ }^{4}$ UNC-Kenan Flagler, USA
}

\begin{abstract}
The Theory of Planned Behaviour (TPB) has been widely applied in the financial sector. However, no research has investigated the moderating role of financial literacy in saving intention. This study investigates the moderating role of financial literacy in the partial influence of money attitude, subjective norms, perceived behavioural control, and perceived risk on saving intention. According to the Moderated Regression Analysis (MRA) findings, financial literacy moderated the effect of money attitude, subjective norms, and perceived behavioural control on saving intention. On the other hand, financial literacy has not mitigated the effect of perceived risk on saving intention. These findings validate TPB's application in the financial sector by incorporating moderating role of financial literacy. It is also discovered that the millennial generations who participate in this study have good financial literacy.
\end{abstract}

Keywords: financial literacy; perceived risk; saving intention; theory of planned behaviour.

Received: March 3, 2021; Accepted: June 3, 2021; Published: October 26, 2021

*Corresponding author

Email: nadia.asandimitra-13@feb.unair.ac.id

\section{To cite this document:}

Asandimitra, N., Narsa., I. M., Irwanto, A., \& Ishartanto, H. (2021). The effect of money attitude, subjective norm, perceived behavioural control, and perceived risk on millennial's saving intention. BISMA (Bisnis dan Manajemen), 14(1), 1-14. https://doi.org/10.26740/bisma.v14n1.p1-14.

\section{INTRODUCTION}

The millennial generation has a relatively large number in Indonesia, around $31.33 \%$ of the Indonesian population and around $46.31 \%$ of Indonesia's total productive age population (BPS, 2020). Therefore, the millennial generation has an 
enormous potential contribution to develop the Indonesian economy. However, two problems are generally experienced by the millennial generation such as consumptive behaviour, low financial ability, and low financial literacy (Hidayatullah et al., 2018; Masyrafina, 2020; Mubarokah \& Rita, 2020; Philip, 2019; Qurotaa'yun \& Krisnawati, 2019; Septy, 2021).

The consumptive behaviour of the millennial generation can harm themselves and the wider community. The negative impact for the millennial generation individually is the potential for various financial problems due to uncontrolled expenses, increasing debt, and the inability to meet basic needs (Qurotaa'yun \& Krisnawati, 2019). The impact for the broader community is the emergence of a consumptive culture (Yudasella \& Krisnawati, 2019). Therefore, it is necessary to encourage saving behaviour for millennial generation's financial health (Maulana et al., 2020; Rameli \& Marimuthu, 2018). TPB stated that attitude, subjective norms, and perceived behavioural control (PBC) could influence intention. Saving as a form of behaviour can be influenced by intention, a mental state that represents a commitment to act (Ajzen \& Fishbein, 1975).

Empirically, there have been several previous studies examining the consumptive behaviour of the millennial generation. For example, Sabri (2016) stated that the millennial generation has a very intense spending frequency, and many of them have large amounts of debt, which indicates a low ability to manage their finances. Also, Tie \& Nizam (2015) stated that the consumptive behaviour of the millennial generation caused by their low financial literacy.

According to Sabri (2016) and Tie \& Nizam (2015), consumptive behaviour is rooted in low financial literacy. Regarding the TPB framework, Qamar et al. (2016) examined the effect of money attitude on financial management behaviour with the moderation of financial knowledge. The findings showed that money attitude and financial knowledge have a significant positive effect on financial management behaviour, and financial knowledge has a positive moderating role in the relationship between money attitude and financial management behaviour. Next, Niazi \& Malik (2019) examined the moderating role of financial literacy in the influence of socio-demographic factors, decision behaviour, and financial attitude towards investment diversification.

Ajzen (1991) stated that the intention to behave is a single predictor of behaviour, and that is, a person's behaviour is very dependent on the intention he has. It can also be said that a person will have a high tendency to carry out a behaviour that is in line with the underlying intentions. Therefore, research that seeks to determine the factors influencing actual behaviour cannot rule out the intention variable. Meanwhile, Niazi \& Malik (2019) and Qamar et al. (2016) examined the moderating role of financial literacy in the relationship between money attitude and financial behaviour without involving analysis of intention.

However, no previous research has examined the moderating role of financial literacy in saving intention. If someone has good financial literacy, it will affect 
Asandimitra, N., Narsa., I. M., Irwanto, A., \& Ishartanto, H. The effect of money attitude, subjective norm, perceived behavioural control, and perceived risk on millennial's saving intention

their accuracy in making decisions about spending their money. As a result, financial literacy will almost certainly keep the millennial generation from excessive spending (Mubarokah \& Rita, 2020; Qurotaa'yun \& Krisnawati, 2019).

Apart from examining the variables in the TPB, this study also includes testing of perceived risk on saving intention. Perceived risk is a consequence that is expected to be accepted and cannot be resolved or anticipated with certainty due to the implementation of an activity (Bauer, 1967). A person can assess the risk level of his financial decision if he has good financial knowledge. Conversely, without good financial knowledge, a person can make inappropriate financial decisions that are detrimental to himself or other related parties (Muzakky \& Soekarno, 2021).

Previous studies about the effect of perceived risk conducted by Niazi \& Malik (2019) which found that financial literacy moderates the effect of risk on financial behaviour in the form of investment diversification. Furthermore, Magendans et al. (2017) found that perceived financial self-efficacy and financial risk tolerance have a significant effect on the intention to save and self-reported saving behaviour.

Referring to TPB, this research examines the effect of money attitude, subjective norms, and perceived behavioural control on saving intention with moderation of financial literacy. The findings of this study are expected to show the critical role of financial literacy in shaping saving intention among the millennial generation in particular and all levels of society in general. The urge to increase saving interest can be a solution for Indonesian millennial's consumptive behaviour and improving the Indonesian financial well-being.

\section{Moderation of Financial Literacy in the Influence of Money Attitude on Saving Intention}

According to Remund (2010), the understanding of financial concepts, or what is known as financial literacy, means a person may have a proclivity to act consumptively or vice versa. Financial literacy is also an ownership of the ability and confidence to manage their finances properly. The greater a person's financial literacy, the stronger their foundation or considerations in making financial decisions. Someone with a high level of financial literacy has a more positive money attitude, which leads to a desire to save money than someone with a lower level of financial literacy. As a result, financial literacy can be viewed as a variable that strengthens the influence of money attitude on saving intention (Servon \& Kaestner, 2008).

The previous research which relevant to this concept are Qamar et al. (2016) which examined the effect of money attitude on financial management behaviour with the moderation of financial knowledge, and Niazi \& Malik (2019) which examined the moderating role of financial literacy in the influence of sociodemographic factors, decision behaviour, and financial attitude towards investment diversification. Therefore, this study seeks to fill the gap in previous studies by 
examining the moderating role of financial literacy in the effect of money attitude on saving intention. Hence, we hypothesize that:

H1: Financial literacy moderates the influence of money attitude on saving intention.

\section{Moderation of Financial Literacy in the Influence of Subjective Norm on Saving Intention}

Subjective norms, according to Fang et al. (2017), are perceived social pressures to perform or not perform a behaviour in certain situations. Pressure can come from parties who are closely related or have a large influence on individual decision making. Subjective norms are behavioural guidelines that are subjective in nature that arise from thoughts or self-perceptions about a thing. The greater the social pressure to support or oppose the norm, the greater the influence on behaviour Based on this stance, the opinions of these parties, whether they are advocating or supporting a particular way of behaving or not behaving, become one of the primary considerations in making decisions (Ajzen, 2011). In general, three groups are thought to have a close relationship or a strong influence on individuals: people regarded as important and whose opinions are respected, friends, and parents (Widyastuti et al., 2016).

According to Ajzen (1991), in the TPB framework, subjective norms are formed by two main factors, namely normative belief and motivation to comply. Understanding various aspects of a behaviour is linked to normative beliefs and motivation to obey oneself against that behaviour. The relationship between normative beliefs and motivation to comply with saving intention in the context of this study depends on the financial literacy. Someone with a high level of financial literacy can make a better objective decision when considering the benefits of saving behaviour, thereby encouraging higher saving intentions. Someone in high supportive behaviour environment with higher financial literacy is more likely to save (Fang et al., 2017).

There is no previous research that specifically examined the moderation role of financial literacy in the effect of subjective norms on saving intention. The previous research related to the moderating role of financial literacy is conducted by Akhtar \& Muhammad (2017) about the moderating role of financial literacy in investment intention. Furthermore, we hypothesize that:

$\mathrm{H} 2$ : Financial literacy moderates the influence of subjective norms on saving intention.

\section{Moderation of Financial Literacy in the Influence of Perceived Behavioural Control on Saving Intention}

Perceived behavioural control, according to Yzer (2012), is a function of belief in resources, opportunities, and other factors that support or hinder the realization of a behaviour. Financial literacy is one type of resource that can 
Asandimitra, N., Narsa., I. M., Irwanto, A., \& Ishartanto, H. The effect of money attitude, subjective norm, perceived behavioural control, and perceived risk on millennial's saving intention

distinguish between people with high and low perceived behavioural control. According to the definition proposed by Servon \& Kaestner (2008), financial literacy is the ability to comprehend and apply financial concepts. As a result, a person with a high level of financial literacy will better understand the things that must be done, the proper method or procedure to behave or carry out a financial management activity, and the perception that the action or behaviour can be carried out properly and easily. Someone with a low level of financial literacy, on the other hand, will be doubtful or unsure about being able to realize a favourable financial behaviour. Thus, financial literacy can strengthen the influence of perceived behavioural control on saving intention.

The research that has the same concept is carried out by Chiou (1998) which examined the moderating role of product knowledge on the influence of attitude, subjective norm, and perceived behavioural control on purchase intention. Therefore, this study seeks to fill the gap in previous research by examining the moderating role of financial literacy in the effect of perceived behavioural control on saving intention. Therefore, a hypothesis that can be proposed in this study is as follows:

H3: Financial literacy moderates the influence of perceived behavioural control on saving intention.

\section{Moderation of Financial Literacy in the Influence of Perceived Risk on Saving Intention}

Perceived risk can be defined as an expected consequence that cannot be avoided or predicted (Bauer, 1967). Perceived risk is a subjective expectation of losses in certain aspects as a result of efforts. The individual can decide whether to continue to engage in the risky behaviour or, conversely, cancel his intention to engage in the risky behaviour (Warkentin et al., 2002).

The risk of a behaviour cannot be known if the individual is unaware of the behaviour and the various consequences if he behaves or does not behave. However, in some cases, individuals do not thoroughly consider the risk of behaviour, so they dare to engage in a behaviour known as risk taking behaviour. On the other hand, some people are extremely cautious and behave in such a way that every risk is considered first and avoided if it appears to have a negative impact (risk averse behaviour) (Nicholson et al., 2005).

Risk assessment is based on the perception of the uncertainty of the consequences that will be received, as well as the ability to deal with these consequences (Mitchell, 1999). Everyone can have different perceived risk, which is primarily determined by several key factors such as personality and situational factors. The personality factor is related to one's perspective on threats and opportunities, whereas the situation factor is related to one's perception of loss or gain (Reniers et al., 2016). 
In the context of this study, someone with high financial literacy will be aware of the risks and consequences that will befall them if they engage in a particular financial behaviour, such as saving or, conversely, spending their money excessively because they are motivated by a desire to follow trends and achieve personal fulfilment. In contrast, if someone lacks financial literacy, their understanding of the risks and consequences of such behaviour is limited, and they are more likely to engage in risky financial behaviour (consumptive). As a result, financial literacy can strengthen the influence of risk perception on saving intention.

Previous research relevant to this concept is Niazi \& Malik (2019), who find that financial literacy moderates the effect of risk on financial behaviour in the form of investment diversification. However, no previous studies examined the moderating role of financial literacy in the effect of perceived risk on saving intention. Therefore, this study seeks to fill this gap to obtain an overview of the importance of perceived risk in the application of TPB in the financial sector. Figure 1 shows conceptual model of this research. Therefore, the following is a hypothesis that can be proposed:

H4: Financial literacy moderates the effect of perceived risk on saving intention.

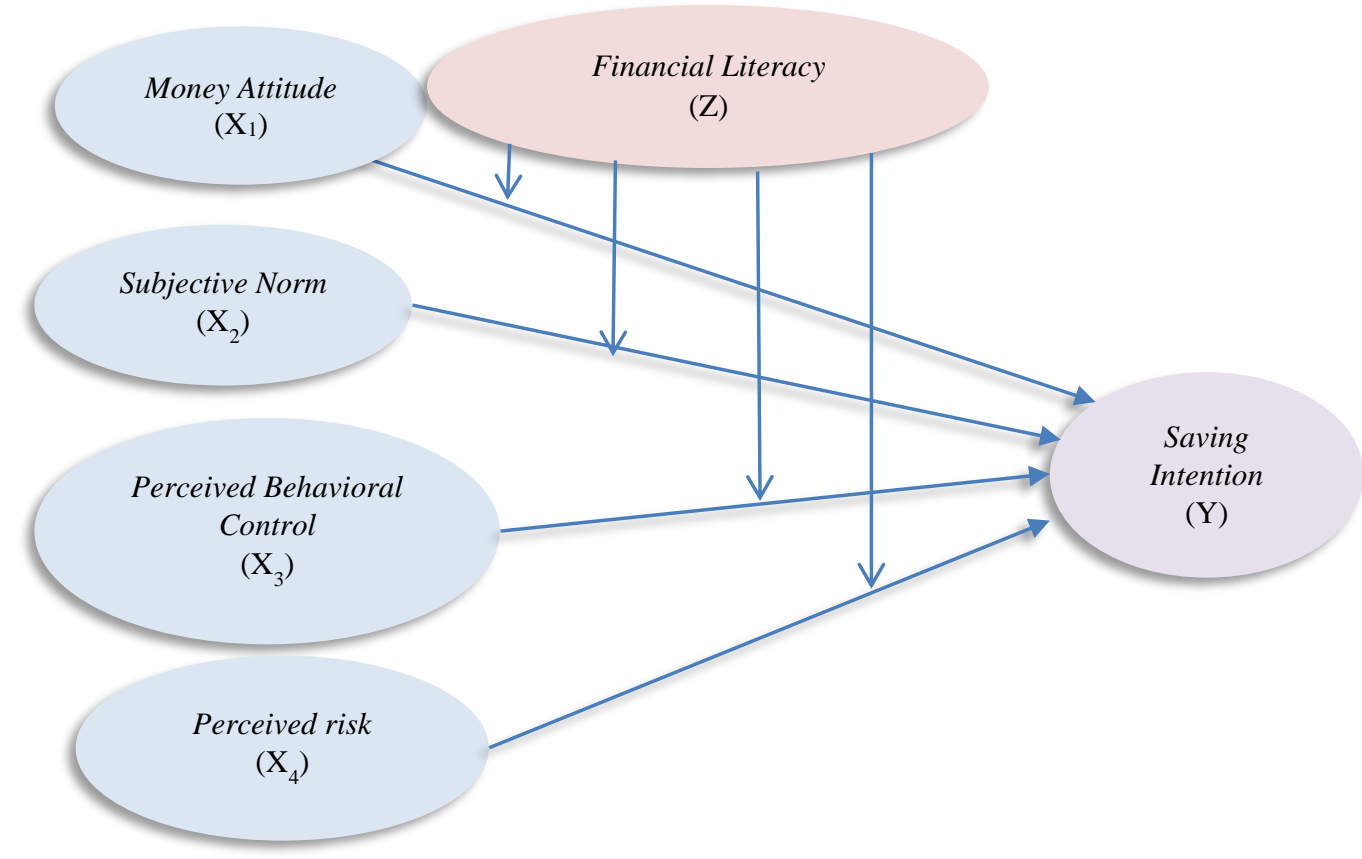

Figure 1. Conceptual Model

\section{METHODS}

The research approach is quantitative. The population consists of all millennial generations in the city of Surabaya, with 1,051,866 people. The percentage of the millennial generation in Surabaya is 35.53 percent of the total population, which is higher than the percentage of the millennial generation in the Indonesian population (BPS, 2021). Furthermore, the purposive sampling technique is used to determine the part of the population as the research sample. 
Asandimitra, N., Narsa., I. M., Irwanto, A., \& Ishartanto, H. The effect of money attitude, subjective norm, perceived behavioural control, and perceived risk on millennial's saving intention

The sample criteria consists of: (1) residing in Surabaya, both natives and immigrants who live in Surabaya; (2) having daily activities that are routinely carried out, such as being a student or worker; (3) born between 1981-2000 (20-39 years old); and (4) millennials with monthly expenditure that equal or exceed to their monthly income. The number of research samples is, by using the Slovin formula, 400 millennial generation people. The data of this study is gathered by using a survey method.

The questionnaire used five Likert scales, starting from strongly disagree to strongly agree. The indicators for measuring each variable are adapted from previous relevant research as shown in Table 1.

Table 1. Measurement of Variables

\begin{tabular}{lcc}
\hline \multicolumn{1}{c}{ Variable } & $\begin{array}{c}\text { Number of } \\
\text { Indicators }\end{array}$ & Source \\
\hline Money attitude & 25 & Lay \& Furnham (2018) \\
Subjective norm & 8 & Nugroho et al. (2018) \\
Perceived & 12 & Ajzen (1991); Bandura (1977); Kang et al. (2006); \\
behavioural control & & Sari \& Rofaida (2011); Yzer (2012) \\
$\begin{array}{l}\text { Perceived risk } \\
\text { Financial literacy }\end{array}$ & 6 & Almousa (2014) \\
Saving intention & 7 & Adomako et al. (2016); Widyastuti et al. (2016) \\
\hline
\end{tabular}

The research data obtained is then tested for validity and reliability using SPSS. Furthermore, hypothesis testing is carried out using multiple regression tests to obtain the first output and absolute difference MRA to obtain the second output.

\section{RESULTS AND DISCUSSION Respondents' Demographic Profile}

Table 2. Demographic Profile

\begin{tabular}{lccc}
\hline \multicolumn{1}{c}{ Variable } & Category & Count & Percentage \\
\hline Gender & Male & 260 & $65 \%$ \\
Age & Female & 140 & $35 \%$ \\
& $20-24$ y.o. & 133 & $33.3 \%$ \\
& $25-29$ y.o. & 144 & $36.0 \%$ \\
Job & $30-34$ y.o. & 56 & $14.0 \%$ \\
& $35-39$ y.o. & 67 & $16.8 \%$ \\
& Civil worker/Military/Police & 119 & $29.8 \%$ \\
Education & Private sector worker & 87 & $21.8 \%$ \\
& Entrepreneur & 134 & $33.5 \%$ \\
& College student & 60 & $15.0 \%$ \\
& High School & 58 & 14.5 \\
& Undergraduate & 282 & 70.5 \\
& Graduate & 60 & 15.0 \\
\hline
\end{tabular}

The results of the descriptive analysis show that most respondents, 240 people or $65 \%$, is male. According to the age group, the respondents are the millennial generation aged 25 to 29 years old, namely 144 people or $36 \%$. According to their work, the millennial generations who became respondents in this study are primarily entrepreneurs, namely 134 people or $33.5 \%$. The latest education of most 
respondents is undergraduate, which number is 282 people or $70.5 \%$. Further details of the demographics of the respondents can be seen in Table 2 .

\section{Hypothesis Testing}

The results of the multiple linear regression test and the MRA of this study can be seen in Table 3 .

Table 3. The Results of Multiple Linear Regression Test and MRA

\begin{tabular}{clcc}
\hline Model & \multicolumn{1}{c}{ Variable } & Beta & Sig \\
\hline 1 & Money Attitude & .048 & .033 \\
& Subjective Norms & -.183 & .000 \\
& Perceived Behaviour Control & .283 & .000 \\
& Perceived risk & .494 & .000 \\
& Financial Literacy & -.024 & .665 \\
& Money Attitude*Financial Literacy & .165 & .006 \\
& Subjective Norms*Financial Literacy & .224 & .007 \\
& Perceived Behaviour Control*Financial Literacy & -.783 & .032 \\
& Perceived risk*Financial Literacy & -.034 & .682 \\
\hline
\end{tabular}

The results indicate that the first hypothesis of this study is accepted. This fact is based on the effect of money attitude (X1) on saving intention (Y) with the moderation of financial literacy $(\mathrm{Z})$, which has a positive unstandardized coefficient value of 0.165 with a significance value of 0.006 , which is smaller than the $5 \%$ significance level. The second hypothesis of the study is also accepted. This is consistent with the effect of subjective norms (X2) on saving intention (Y) with the moderation of financial literacy $(\mathrm{Z})$, which has a positive unstandardized coefficient value of 0.224 with a significance value of 0.007 which is smaller than the $5 \%$ significance level. The third hypothesis of this study is also accepted following the effect of perceived behavioural control (X3) on saving intention (Y) with the moderation of financial literacy $(\mathrm{Z})$, which has a negative unstandardized coefficient value of 0.783 with a significance value of 0.032 , which is smaller than the $5 \%$ significance level. However, the fourth hypothesis of this study is rejected because the effect of perceived risk (X4) on saving intention (Y) with the moderation of financial literacy $(Z)$ has an effect significance value of 0.682 , which is greater than the $5 \%$ significance level.

Following the results, the moderator role of financial literacy in the partial influence of money attitude, subjective norms, and perceived behavioural control on saving intention is the pure moderator. This means that financial literacy has a pure role as a moderator in this model and does not become an independent variable that influences saving intention.

\section{Discussion}

This study can prove three of four hypotheses developed. The first proven hypothesis is hypothesis 1 that financial literacy moderates the effect of money attitude on saving intention. According to the findings, millennials' money attitudes can further encourage their saving intention in line with their higher financial 
Asandimitra, N., Narsa., I. M., Irwanto, A., \& Ishartanto, H.

The effect of money attitude, subjective norm, perceived behavioural control, and perceived risk on millennial's saving intention

literacy. However, there are some previous studies that are relevant to the concept, such as research by Qamar et al. (2016) and Niazi \& Malik (2019).

The second proven hypothesis is hypothesis 2 which states that financial literacy moderates the effect of subjective norms on saving intention. Saving intention can arise not only because of a high level of financial literacy but also because of the influence of the surrounding environment that directs to save or simply does not exemplify consumptive behaviours. The findings of this study contradict the previous research conducted by Akhtar \& Muhammad (2017). While it does not explicitly test the same variables within the scope of TPB, it has similar research focus with this research.

The third proven hypothesis states that financial literacy encourages a weaker influence of perceived behavioural control on saving intention because perceived behavioural control is more related to the perceived ease of saving. In this case, millennials may consider factors such as their income, which is still insufficient to meet their daily needs, or environmental factors that encourage consumption, such as the number of shopping centres in Surabaya and the ease of shopping through online shops. This findings are consistent with the previous research conducted by Chiou (1998) who shows that product knowledge can moderate the influence of perceived behavioural control on purchase intention.

The unproven hypothesis is the fourth hypothesis which states that financial literacy has not been proven to moderate the influence of perceived risk on saving intention. Therefore, if millennials understand the self-financial condition about well-being or adequacy in financial aspects, they will aware about the consumptive behaviour risk. Finally, millennials able to shift from a consumerist to a frugal and saving-oriented mindset. One possible factor is millennials' lack of understanding regarding the concept of risk. The findings of this study regarding this point contradict the findings of Niazi \& Malik (2019) who show that financial literacy moderates the influence of risk on financial behaviour through investment diversification.

Another finding from this study explained that the financial literacy of the millennial generation has excellent literacy. In addition, it can be seen that financial literacy can strengthen the influence of the surrounding environment, especially from families, in fostering saving intention in millennial generation. However, there are indications that the respondents of this study still had difficulty realizing their intention to save. Despite having good financial literacy, millennials still have in sufficient financial conditions so they cannot share their income for savings.

Financial literacy has a negative moderating effect on saving intention when compared to perceived behavioural control. This demonstrates that financial literacy increased confidence in self-control to save rather than perceived behavioural control. The negative moderation of financial literacy shows that millennial generation consider other factors in saving such as income or consumptive behaviour. 
However, financial literacy has not moderated the effect of perceived risk on saving intention, and does not automatically increase understanding of the risks of consumptive behaviour. In other words, there is no common thread that connects the understanding of financial literacy and financial conditions with the risk factors of millennial consumptive behaviour. Overall, this study produces findings that can be used to develop TPB for analysis in the financial sector.

The study result indicates that the powerful influence of referrals (family environment and social community) to saving intention. Hence, the millennial generation need to have environment that can influence them to avoid consumptive behaviour.

\section{CONCLUSION}

According to TPB, this study can prove the moderating role of financial literacy in influencing three predictors of behaviour: money attitude, subjective norms, and perceived behavioural control, on saving intention. However, financial literacy is not able to moderate the effect of perceived risk on saving intention. These results explain the importance of financial literacy in increasing the saving intention of the millennial generation and keeping them away from consumptive behaviour.

There are four limitations of this study. First, the study does not investigate the characteristics of respondents based on their income level or marital status. Indeed, these two characteristics can potentially elucidate the saving intentions of Surabaya millennials who participated in this study. Second, this study is unable to explain millennials' saving habits other than saving and investing. Other alternative saving behaviours tend to provide greater financial benefits than just saving and investing. Third, this study relies on self-reported data, with respondents asked to complete questionnaires explaining the research variables. Therefore, the study cannot adequately describe the financial literacy aspects owned by respondents. Fourth, this study only included one moderating variable, financial literacy, which does not moderate the impact of perceived risk on saving intention. Further research can include other moderation variables that can improve the research model, particularly the impact of perceived risk on saving intention. The triple helix model which involves collaboration between three social actors - the university, the private sector, and the government - with the goal of fostering regional innovation development for investment or saving movement are also interesting to be a further research avenue.

\section{REFERENCES}

Adomako, S., Danso, J., \& Damoah, J.O. (2016). The Moderating Influence of Financial Literacy on The Relationship Between Access to Finance And Firm Growth in Ghana. Venture Capital, 18(1), 43-61. https://doi.org/10.1080/13691066.2015.1079952. 
Asandimitra, N., Narsa., I. M., Irwanto, A., \& Ishartanto, H. The effect of money attitude, subjective norm, perceived behavioural control, and perceived risk on millennial's saving intention

Ajzen, I. (1991). The Theory of Planned Behavior. Organizational Behaviora and Human Decision Processes, 50(2), 179-211. https://doi.org/10.1016/07495978(91)90020-T.

Ajzen, I. (2011). The theory of planned behavior: reactions and reflections. Psychological \& Health, 26(9), 1113-1127. https://doi.org/10.1080/08870446.2011.613995.

Ajzen, I., \& Fishbein, M. (1975). Belief, Attitude, Intention, and Behavior. An Introduction to Theory and Research, 129-385. https://people.umass.edu/aizen/f\&a1975.html.

Akhtar, M., \& Muhammad, F. (2017). Financial Sophistication , Emotional Quotient, and Stock Market Participation : Theory and Evidence. Journal of Islamic Business and Management, 7(1), 87-99. https://doi.org/10.26501/jibm/2017.0701-007.

Almousa, M. (2014). The influence of risk perception in online purchasing behavior: Examination of an early-stage online market. International Review of Management and Business Research, 3(2), 779.

Bandura, A. (1977). Self-efficacy: Toward a unifying theory of behavioral change. Psychological Review, 84, 122-147. https://doi.org/10.1037/0033295X.84.2.191.

Bauer, R. A. (1967). Consumer Behavior as Risk-Taking, Dynamic Marketing for Changing World. American Marketing Association.

BPS. (2020). "Jumlah Penduduk Menurut Kelompok Umur dan Jenis Kelamin". $\begin{array}{llll}\text { Retrived January } & 5 & 2021 & \text { from }\end{array}$ https://www.bps.go.id/indikator/indikator/view_data_pub/0000/api_pub/Y W40a21pdTU1cnJxOGt6dm43ZEdoZz09/da_03/1.

BPS. (2021). "Proyeksi Penduduk Kota Surabaya Menurut Jenis Kelamin dan Kelompok Umur". Retrived January 5 2021 from https://surabayakota.bps.go.id/dynamictable/2018/04/18/24/proyeksipenduduk-kota-surabaya-menurut-jenis-kelamin-dan-kelompok-umurtahun-2020.html.

Chiou, J.-S. (1998). The Effects of Attitude, Subjective Norm, and Perceived Behavioral Control on Consumers' Purchase Intentions: The Moderating Effects of Product Knowledge and Attention to Social Comparison Information. Proceedings of the National Science Council, 9(2), 298-398. http://citeseerx.ist.psu.edu/viewdoc/download?doi=10.1.1.202.7526\&rep=re p1\&type $=$ pdf.

Fang, W. T., Ng, E., Wang, C. M., \& Hsu, M. L. (2017). Normative Beliefs, Attitudes, and Social Norms: People Reduce Waste as an Index of Social Relationships When Spending Leisure Time. Sustainability, 9(10), 1-18. 
https://doi.org/10.3390/su9101696.

Hidayatullah, S., Waris, A., \& Devianti, R. C. (2018). Perilaku Generasi Milenial dalam Menggunakan Aplikasi Go-Food. Jurnal Manajemen Dan Kewirausahaan, 6(2), 240-249. https://doi.org/10.26905/jmdk.v6i2.2560.

Kang, H., Hahn, M., Fortin, D., Hyun, Y.J., \& Eom, Y. (2006). Effects of perceived behavioral control on the consumer usage intention of e-coupons. Psychology and Marketing, 23(10), 841-864. https://doi.org/10.1002/mar.20136.

Lay, A., \& Furnham, A. (2018). A New Money Attitudes Questionnaire. European Journal of Psychological Assessment, 35(6), 1-10. https://doi.org/10.1027/1015-5759/a000474.

Magendans, J., Gutteling, J. M., \& Zebel, S. (2017). Psychological determinants of financial buffer saving: the influence of financial risk tolerance and regulatory focus. Journal of Risk Research, 20(8), 1076-1093. https://doi.org/10.1080/13669877.2016.1147491.

Masyrafina, I. (2020). "OJK: Literasi Keuangan Milenial Masih Rendah". Republika.Co.Id. Retrived January 5 2021 from https://republika.co.id/berita/qkpmzl383/ojk-literasi-keuangan-milenialmasih-rendah.

Maulana, I., Manulang, J. M. br., \& Salsabila, O. (2020). Pengaruh Social Media Influencer Terhadap Perilaku Konsumtif di Era Ekonomi Digital. Majalah Ilmiah Bijak, 17(1), 28-34. http://dx.doi.org/10.23887/ijssb.v4i2.24139.

Mitchell, V. W. (1999). Consumer perceived risk: Conceptualisations and models. European Journal of Marketing, 33(1), 163-195. https://doi.org/10.1108/03090569910249229.

Mubarokah, S., \& Rita, M. R. (2020). Anteseden Perilaku Konsumtif Generasi Milenial: Peran Gender Sebagai Pemoderasi. International Journal of Social Science and Business, 4(2), 211-220. https://dx.doi.org/10.23887/ijssb.v4i2.24139.

Muzakky, F. A., \& Soekarno, S. (2021). How financial literacy affect risk preference: an evidence from Bandung, Indonesia. Jurnal Riset Akuntansi Dan Keuangan, 9(1), 1-12.

Niazi, M. K. S., \& Malik, Q. A. (2019). Financial Attitude and Investment Decision Making - Moderating Role of Financial Literacy. NUML International Journal of Business \& Management, 14(1), 102-115.

Nicholson, N., Soane, E., O’Creevy, M. F., \& Willman, P. (2005). Personality and domain-specific risk taking. Journal of Risk Research, 8(2), 157-176. https://doi.org/10.1080/1366987032000123856.

Nugroho, A., Najib, M., \& Simanjutak, M. (2018). Factors Affecting Consumer 
Asandimitra, N., Narsa., I. M., Irwanto, A., \& Ishartanto, H.

The effect of money attitude, subjective norm, perceived behavioural control, and perceived risk on millennial's saving intention

Interest in Electronic Money Usage With Theory of Planned Behavior (TPB). Journal of Consumer Sciences, 3(1), 15-27. https://doi.org/10.29244/jcs.3.1.15-27.

Philip. (2019). Pengaruh Gaya Hidup Terhadap Keputusan Pembelian Dengan Perilaku Konsumtif Sebagai Variabel Intervening Pada Pembelian Sneakers Branded Oleh Generasi Z Di Surabaya. Agora, 7(2).

Qamar, M. A. J., Khemta, M. A. N., \& Jamil, H. (2016). How Knowledge and Financial Self-Efficacy Moderate the Relationship between Money Attitudes and Personal Financial Management Behavior. European Online Journal of Natural and Social Sciences, 5(2), 296-308.

Qurotaa'yun, Z., \& Krisnawati, A. (2019). Pengaruh Literasi Keuangan Terhadap Perilaku Konsumtif Generasi Milenial Di Kota Bandung. JAF- Journal of Accounting and Finance, 3(1), 46-53. https://doi.org/10.25124/jaf.v3i1.2167.

Rameli, R. S., \& Marimuthu, M. (2018). A Conceptual Review on the Effect of Attitudes towards Retirement on Saving Intentions and Retirement Planning Behavior. SHS Web of Conferences, 56, 1-6. https://doi.org/10.1051/shsconf/20185602005.

Remund, D. L. (2010). Financial Literacy Explicated: The Case for a Clearer Definition in an Increasingly Complex Economy. The Journal of Consumer Affairs, 44(2), 276-295. https://doi.org/10.1111/j.1745-6606.2010.01169.x.

Reniers, R. L. E. P., Murphy, L., Lin, A., Bartolomé, S. P., \& Wood, S. J. (2016). Risk Perception and Risk-Taking Behaviour during Adolescence: The Influence of Personality and Gender. Plos One, 11(4), 1-14. https://doi.org/10.1371/journal.pone.0153842.

Sabri, N. A. A. (2016). The Relationship between the Level of Financial Literacy and Investment Decision-Making Millennials in Malaysia. Taylor's Business Review, 6(1), 39-47.

Sari, M., \& Rofaida, R. (2011). Factors Affecting The Behavior of University Community to Use Credit Card. International Research Journal of Business Studies, 4(3), 217-228. https://doi.org/10.21632/irjbs.4.3.217-228.

Septy, R. (2021). "Tingkat literasi keuangan milenial di Indonesia masih rendah". Diskominfo Prov. Kaltim. Retrived January 5 2021 from https://diskominfo.kaltimprov.go.id/ekonomi/tingkat-literasi-keuanganmilenial-di-indonesia-masih-rendah.

Servon, L. J., \& Kaestner, R. (2008). Consumer financial literacy and the impact of online banking on the financial behavior of lower-income bank customers. Journal of Consumer Affairs, 42(2), 271-305. https://doi.org/10.1111/j.17456606.2008.00108.x. 
Tie, S. C., \& Nizam, I. (2015). Determinants of Financial Well-Being For Generation Y in Malaysia. International Journal of Accounting \& Business Management, $3(2)$, 11-28. https://doi.org/10.24924/ijabm/2015.11/v3.iss2/11.28.

Warkentin, M., Gefen, D., Pavlou, P. A., \& Rose, G. M. (2002). Encouraging citizen adoption of e-government by building trust. Electronic Markets, 12(3), 157-162. https://doi.org/10.1080/101967802320245929.

Widyastuti, U., Suhud, U., \& Sumiati, A. (2016). The Impact of Financial Literacy on Student Teachers' Saving Intention and Saving Behaviour. Mediterranean Journal of Social Sciences, 7(6), 41-48. https://doi.org/10.5901/mjss.2016.v7n6p41.

Yudasella, I. F., \& Krisnawati, A. (2019). Pengaruh Literasi Keuangan Terhadap Perilaku Konsumtif Siswa Sekolah Menengah Atas di Kota Bandung. Jurnal Mitra Manajemen, 3(1), 147-162. https://doi.org/10.52160/ejmm.v3i6.245.

Yzer, M. (2012). Perceived behavioral control in reasoned action theory: A dualaspect interpretation. In Annals of the American Academy of Political and Social Science, 640(1), 101-117. https://doi.org/10.1177/0002716211423500. 